\title{
Determination of conjugated oestrogens in maternal blood plasma and urine for pregnancy diagnosis and monitoring of foetal well-being in the mare
}

\author{
G. Schuler and B. Hoffmann \\ Klinik für Geburtshilfe, Gynäkologie und Andrologie der Groß- und Kleintiere mit tierärztlicher Ambulanz, Justus-Liebig-Universität Giessen
}

\begin{abstract}
Summary
Due to the distinct differences of oestrogen concentrations in pregnant and non-pregnant animals the radioimmunological determination of conjugated oestrogens in maternal blood plasma or serum is a highly reliable method for pregnancy diagnosis in mares during the interval corresponding to the phase of placental oestrogen production between around days 70-80 after mating/insemination and parturition. As placental oestrogen biosynthesis depends on precursors provided by the foetal gonads, any loss of foetal vitality is strictly associated with a decreased placental oestrogen production. Therefore, oestrogen concentrations are a useful parameter for the monitoring of foetal wellbeing in cases of unclear symptoms of impaired pregnancy. Prior to the onset of placental oestrogen production determination of ovarian estrone sulfate can aiso be applied (> day 40). However, pregnancy diagnosis may be problematic due to slightly overlapping values between $1 \mathrm{ng} / \mathrm{ml}$ to $2.5 \mathrm{ng} / \mathrm{ml}$ likewise occurring in mares at oestrus and a minor fraction of pregnant mares. The determination of urinary conjugated oestrogens can be used as a non-invasive alternative to the measurement in blood plasma within the interval corresponding to the phase of placental oestrogen production ( $>$ day 80 ). Preliminary results also suggest that ovarian oestrogen production between days 40 and 80 after mating (insemination) may be monitored for pregnancy diagnosis, but the preliminary cut-off level at $175 \mathrm{ng} / \mathrm{ml}$ needs further confirmation.
\end{abstract}

Keywords: $\quad$ horse, pregnancy diagnosis, oestrogens, blood, urine

\begin{abstract}
Messung konjugierter Blut- und Harnöstrogene zur Graviditätsdiagnose und Überwachung der Fetusvitalität beim Pferd
Die trächtigkeitsspezifische Östrogenproduktion der Stute kann entsprechend der Östrogenquellen in zwei Phasen eingeteilt werden. In der ersten Phase findet sich im peripheren maternalen Plasma nach einem ersten Anstieg um den 40. Graviditätstag eine leichte Erhöhung der Estronsulfatkonzentrationen von Basalniveau $(<0,5 \mathrm{ng} / \mathrm{ml})$ auf $1,5-10 \mathrm{ng} / \mathrm{ml}$ bis zum ca. $70 .-80$. Graviditätstag. Als Östrogenquelle fungiert hierbei das Ovar. In der folgenden plazentaren Phase kommt es im maternalen Blutplasma zu einem steilen Anstieg der Konzentrationen konjugierter Östrogene auf Maximalwerte um $700 \mathrm{ng} / \mathrm{ml}$ in der Graviditätsmitte, gefolgt von einem allmählichen Abfall auf Werte um 50-100 $\mathrm{ng} / \mathrm{ml}$ unmittelbar vor der Geburt. Unter der Geburt fallen die Östrogenkonzentrationen weiter steil auf Basalniveau ab. Aufgrund der außerordentlich hohen Östrogenkonzentrationen in der plazentaren Phase stellt die radioimmunologische Bestimmung konjugierter Östrogene in Blutplasma oder -serum ab dem 80. Tag nach der Bedeckung/Besamung eine äußerst zuverlässige Methode zur hormonellen Trächtigkeitsdiagnose dar. Da die Präkursoren der plazentaren Östrogene den fetalen Gonaden entstammen, ist eine Beeinträchtigung der Vitalität des Fohlens stets mit einem Abfall der plazentaren Östrogene verbunden. Daher eignet sich die Östrogenbestimmung auch zur Trächtigkeitsüberwachung in Fällen unklarer Symptome eines drohenden Abortes. Auch zwischen dem 40.-80. Graviditätstag ist in den allermeisten Fällen eine Trächtigkeitsdiagnose anhand der Bestimmung konjugierter Östrogene möglich. Schwierigkeiten können sich hier in einzelnen Fällen durch die geringfügig überlappenden Meßwerte rossiger bzw. frühgravider Stuten im Bereich zwischen 1,0 und 2,5 ng/ml ergeben. Neben der Bestimmung im Blutplasma kann in dem der plazentaren Phase entsprechenden Zeitraum auch die Messung konjugierter Östrogene im Urin als nichtinvasive alternative Methode angewandt werden. Vorläufige Ergebnisse deuten an, daß auch in der der ovariellen Phase entsprechenden Zeitspanne (Tag 40-80) anhand der Östrogenkonzentrationen im Urin eine Aussage hinsichtlich des Bestehens einer Gravidität möglich ist. Der vorläufige Grenzwert von $175 \mathrm{ng} / \mathrm{ml}$ bedarf jedoch einer weiteren Bestätigung durch eine größere Anzahl von Tieren.
\end{abstract}

Schlüsselwörter: Pferd, Trächtigkeitsdiagnose, Östrogene, Blut, Urin

\section{Introduction}

Due to the limited breeding season an accurate pregnancy diagnosis as soon as possible after the last mating or insemination is of outstanding importance for horse breeders. Ultrasonography-aided rectal palpation has become the standard method which allows precise and early confirmation of singleton and twin pregnancies from day 18 onward concomitant with the provision of information about the viability of the foetus (McKinnon et al., 1993; Shideler, 1993). However, in spite of this situation there is still room for hormonal pregnancy diagnosis which may be even more advantageous in certain situations such as pregnancy diagno- sis in vicious mares or if the investigation must be performed under otherwise unsuitable conditions, in small races and donkeys and in animals with injured rectum. Furthermore, hormonal pregnancy diagnosis can be used to verify the diagnosis in cases of uncertain rectal diagnosis, especially at later stages of pregnancy when the enlarged uterus is not sufficiently accessible to examination. Hormonal pregnancy diagnosis may also be an alternative for less experienced, non-specialised practitioners in doubtful cases. Moreover, there is an increasing interest of horse owners in non-invasive and therefore more economical me- 
thods. Non-invasive methods are also of special interest in wild equids or zoo animals. Several methods of hormonal pregnancy diagnosis in horses are available such as progesterone measurement in blood at the time of the next oestrus in case of unsuccessful breeding, the detection of equine chorionic gonadotrophin in blood (Hoffmann et al., 1996), the measurement of pregnancy-associated oestrogens in blood, urine (Schuler, 1998) or faeces (Möstl et al., 1983; Palme et al., 1989) or the determination of faecal concentrations of pregnancy-specific gestagens (Schwarzenberger et al., 1989). In our laboratory, hormonal pregnancy diagnosis is routinely performed by radioimmunological determination of total estrone in blood plasma or serum, and - as a non-invasive alternative - in urine.

In the mare large amounts of oestrogens are produced during pregnancy with sulfoconjugated forms dominating by far over free ones (Hoffmann et al., 1996). Equine pregnancy associated oestrogen production can be divided into two phases according to the source of oestrogens. A first rise of ovarian origin from basal levels below $0.5 \mathrm{ng} / \mathrm{ml}$ up to plasma concentrations between $1.5-10 \mathrm{ng} / \mathrm{ml}$ commences around day 40 of gestation (Daels et al., 1990; Hoffmann et al., 1996), followed by a plateau until around day 80 , when placental oestrogen production increases sharply providing plasma concentrations up to values around 700 $\mathrm{ng} / \mathrm{ml}$ at midgestation. Thereafter oestrogen concentrations decline progressively reaching values of about $100 \mathrm{ng} / \mathrm{ml}$ in the last week of gestation. The final drop occurs immediately prior to parturition and baseline levels are reached 1-2 days post partum (Hoffmann et al., 1996). Since in the horse oestrogens are predominantly excreted via the urine (Palme et al., 1996), the urinary oestrogen profile is basically identical to the one in blood plasma but on a 100-1000-fold higher level (Evans et al., 1984; Monfort et al., 1991).

\section{Material and methods}

Determination of pregnancy-specific oestrogens in blood plasma or serum

The radioimmunoassay (RIA) used for the determination of pregnancy associated oestrogens was adopted from Gentz (1994) and modified for routine performance. Since in the mare sulfoconjugated forms dominate by far over the free ones, no separate estimation of free and conjugated oestrogens was intended and they were determined as total estrone equivalents after hydrolysis of the conjugates. For hydrolysis of conjugated oestrogens, $160 \mu \mathrm{l} 625 \mathrm{mM}$ acetate buffer $\mathrm{pH} 4.8$ and $50 \mu \mathrm{l}$ diluted $\beta$-glucuronidase-arylsulfatase from helix pomatia (Serva Feinbiochemika GmbH\&Co, D-69155 Heidelberg; diluted 1:25 in 0.15 M $\mathrm{NaCl})$, were added to plasma or serum samples $(0.4 \mathrm{ml})$. After an overnight incubation at $37^{\circ} \mathrm{C}$ oestrogens were extracted with toluene. To ensure redissolution of the extracted oestrogens, $160 \mu l 0.1 \mathrm{~N} \mathrm{NaOH}$ with $0.1 \%$ rat serum albumin were added to the evaporated samples which were then incubated for $20 \mathrm{~min}$ at room temperature. Neutralisa- tion and adjustment to RIA conditions were achieved by the addition of $20 \mu \mathrm{l} 0.8 \mathrm{~N} \mathrm{HCl}$ and $20 \mu \mathrm{l}$ concentrated phosphate buffer $\left(8.356 \mathrm{~g} \mathrm{Na}_{2} \mathrm{HPO}_{4}, 2.686 \mathrm{~g} \mathrm{KH}_{2} \mathrm{PO}_{4}\right.$, and $0.325 \mathrm{~g} \mathrm{NaN}_{3}$ ). Depending on the stage of gestation the redissolved samples were then further diluted prior to RIA. When taking $1.0 \mathrm{ml}$ as a starting position the final dilutions varied between 1:5 and 1:1000. In order to obtain exact values in case of low oestrogen concentrations, the 1:5dilution was measured of each sample, irrespective of the assumed stage of gestation. Paired dilutions of $1: 5$ and 1:500 were chosen for samples provided without any anamnestic information. The antiserum used was directed against estrone (Hoffmann et al., 1994) and exhibited the following cross reactions: estrone: $100 \%$, equilenine: $23.83 \%$, equiline: $7.28 \%$, estradiol-17 $\beta: 1.94 \%$, estradiol-17 $\alpha$ : $1.02 \%$, estriol: $0.06 \%$. Concentrations of estrone equivalents were calculated by comparison with a standard curve consisting of eight standards between $20 \mathrm{fmol}$ and 3200 fmol estrone/tube. Intra- and interassay coefficients of variation varied between $9.4 \%$ and $12.5 \%$. Classification of estrone concentrations as indicative for pregnancy was based on the data of Hoffmann et al. (1996).

\section{Determination of pregnancy-specific oestrogens in urine}

The procedure for the measurement of pregnancy associated oestrogens in urine was identical to the method described above for the determination in blood plasma and serum. Due to the considerably higher oestrogen concentrations in urine, dilutions of $1: 500$ and 1:50000 were chosen for all urine samples.

\section{Results and discussion}

Due to the distinct differences of oestrogen concentrations in pregnant and non-pregnant mares the determination of conjugated oestrogens in maternal blood plasma is a highly reliable method for pregnancy diagnosis during the phase of placental oestrogen production lasting from around day 70-80 of gestation until parturition. As placental oestrogen biosynthesis depends on precursors provided by the foetal gonads (reviewed by Möstl, 1994), any loss of foetal vitality strictly coincides with a decreased placental oestrogen production (Kasman et al., 1988; Hoffmann et al., 1996). Thus, oestrogen concentrations are a useful parameter for the monitoring of foetal well-being in cases of unclear symptoms and suspected impaired pregnancies. Accordingly, with the exception of one case, all mares exhibiting estrone concentrations clearly below the respective normal range aborted within one to five days. The exception refers to one mare which gave birth to an abnormally small but viable foal after a prolonged gestation of 420 days. There subnormal concentrations of estrone equivalents around $3-6 \mathrm{ng} / \mathrm{ml}$ (normal range: $50-200 \mathrm{ng} / \mathrm{ml}$ ) were observed in the last two weeks of gestation. On the other hand, mares with threatened abortions showing normal oestrogen concentrations 
maintained pregnancy throughout the time of observation in the clinic. Apart from subnormal oestrogen concentrations also extraordinarily high values can be indicative for impaired gestation (Hoffmann et al., 1996). Furthermore, twin pregnancies are associated with oestrogen levels in the upper range.

Prior to the onset of placental oestrogen production determination of estrone sulfate of ovarian origin can also be applied. However, pregnancy diagnosis may be problematic due to slightly overlapping values between 1 to $2.5 \mathrm{ng} / \mathrm{ml}$ likewise occurring in mares at oestrus (Makawiti et al., 1983; Koskinen et al., 1989) and a minor fraction of eCGpositive mares (Schuler, 1998). However, since the detection of eCG and not the positive outcome of gestation was used to classify animals as pregnant, no information is available if pregnancy was still intact at the time of testing as eCG production can persist for a relatively long time after foetal death (Hoffmann et al., 1996). Hence the "true" cutoff level might be somewhat higher. This is indicated by preliminary results from the additional progesterone determination in cases of doubtful oestrogen concentrations; all samples tested for progesterone because of oestrogen levels within the overlapping range exhibited concentrations which were not consistent with early pregnancy $(<1.5 \mathrm{ng} / \mathrm{ml}$; Hoffmann et al., 1996).

The same radioimmunological method is applicable for the determination of urinary oestrogens which allows the replacement of the overcome chemical assays of Cuboni (1934) or Rommel (1964). Due to the extremely high concentrations exceeding $56 \mu \mathrm{g} / \mathrm{ml}$ at midgestation the determination of urinary oestrogen levels is a very reliable method for non-invasive pregnancy diagnosis.

First results of urinary oestrogen determination also suggest that ovarian oestrogen production between days 50 and 80 after mating (insemination) may be monitored for pregnancy diagnosis; however, the preliminary cut-off level at 175 $\mathrm{ng} / \mathrm{ml}$ needs further confirmation.

\section{Literature}

Cuboni, E. (1934): Una rapida reazione di gravidanza nella cavalla. Clin. vet. (Milano) 57, 85

Daels, P.F., Shideler, S., Lasley, B.L., Hughes, J.P. and Stabenfeldt, G.H. (1990): Source of oestrogen in early pregnancy in the mare. J. Reprod. Fert. 90, 55-61

Evans, K.L., Kasman, L.H., Hughes, J.P., Couto, M. and Lasley, B.L. (1984): Pregnancy diagnosis in the domestic horse through direct urinary estrone conjugate analysis. Theriogenology 22, 615-620

Gentz, F. (1994): Untersuchungen zur endokrinen Kontrolle der Gravidität bei der Stute. Diss. med. vet., Giessen

Hoffmann, B., Höveler, R., Nohr, B. and Hasan, S.H. (1994): Investigations on hormonal changes around parturition in the dog and the occurrence of pregnancy-specific non conjugated oestrogens Exp. Clin. Endocrinol. 102, 185-189

Hoffmann, B., Gentz, F. and Failing, K. (1996): Investigations into the course of progesterone-, oestrogen- and eCG-concentrations du- ring normal and impaired pregnancy in the mare. Reprod. Dom. Anim. 31, 717-723

Kasman, L.H., Hughes, J.P., Stabenfeldt, G.H., Starr, M.D. and Lasley, B.L. (1988): Estrone sulfate concentrations as an indicator of fetal demise in horses. Am. J. Vet. Res. 49, 184-187

Koskinen, E., Kuntsi, H., Lindenberg, H. and Katila, T. (1989): Predicting of ovulation in the mare on the basis of follicular growth and serum oestrone sulphate and progesterone levels. J. Vet. Med. A 36, 299-304

Makawiti, D.W., Allen, W.E. and Kilpatrick, M.J. (1983): Changes in oestrone sulphate concentrations in peripheral plasma of pony mares associated with follicular growth, ovulation and early pregnancy. J. Reprod. Fert. 68, 481-487

McKinnon, A.O., Voss, J.L., Squires, E.L. and Carnevale, E.M. (1993): Diagnostic ultrasonography. In: Equine reproduction, McKinnon, A.O. and Voss, J.L. (Hrsg.), Lea \& Febiger, Philadelphia London, 266-302

Möstl, E., Nöbauer, H., Choi, H.S., Wurm, W. and Bamberg, E. (1983): Trächtigkeitsbestimmung bei der Stute mittels Östrogenbestimmung im Kot. Der praktische Tierarzt 6, 491-492

Möstl, E. (1994): The horse feto-placental unit. Exp. Clin. Endocrinol. 102, 166-168

Monfort, S.L., Arthur, N.P. and Wildt, D.E. (1991): Monitoring ovarian function and pregnancy by evaluating excretion of urinary oestrogen conjugates in semi-free-ranging Przewalski's horses (Equus przewalskii). J. Reprod. Fert. 91, 155-164

Palme, R., Fischer, P., Schilddörfer, H. and Ismail, M.N. (1996): Excretion of infused ${ }^{14} \mathrm{C}$-steroid hormones via faeces and urine in domestic livestock. Anim. Reprod. Sci. 43, 43-63

Rommel, P. (1964): Vergleichende Untersuchungen über die Ausscheidung östrogener Hormone bei landwirtschaftlichen Nutztieren. V. Congr. Int. par la Riprod. Anim. e la Fecond. Artific., Trento, 519-526

Schuler, G. (1998): Indirekte Graviditätsdiagnostik bei der Stute - Erfahrungen mit der Bestimmung des Estronsulfatgehaltes im Blutplasma und im Urin. Prakt. Tierarzt 79, 43-49

Shideler, R.K. (1993): Rectal palpation. In: Equine reproduction, McKinnon, A.O. and Voss, J.L. (Hrsg.), Lea \& Febiger, Philadelphia London, 204-211

Schwarzenberger, F., Pammer, J., Möstl, E., Bamberg, E., Schmehlik, O. (1989): Gestagen- und Östrogenkonzentration im Kot von trächtigen Stuten. Zuchthygiene 24, 157
G. Schuler

B. Hoffmann

Klinik für Geburtshilfe

Gynäkologie und Andrologie

der Groß- und Kleintiere mit tierärztlicher Ambulanz

Justus-Liebig-Universität Giessen

Frankfurter Straße 106

35392 Gießen

Tel.: 0641 - 9938704

Fax: 0641 - 9938709 